\title{
KLASIFIKASI KUALITAS TANAMAN CABAI MENGGUNAKAN METODE FUZZY K-NEAREST NEIGHBOR (FKNN)
}

\author{
Angga Aditya Indra Wiratmaka ${ }^{1}$, Imam Fahrur Rozi ${ }^{2}$, Rosa Andrie Asmara $^{3}$ \\ ${ }^{1,2,3}$ Program Studi Teknik Informatika, Jurusan Teknologi Informasi, Politeknik Negeri Malang \\ Jl. Soekarno-Hatta No. 09 Malang 65141 \\ 12angga2893@gmail.com, ${ }^{2}$ imam.rozi@polinema.ac.id, ${ }^{3}$ rosa.andrie@polinema.ac.id
}

\begin{abstract}
Abstrak
Pada penelitian kali ini akan membahas tentang Klasifikasi Kualitas Tanaman Cabai Menggunakan Metode Fuzzy K-Nearest Neighbor(FKNN). Hal tersebut dilatarbelakangi karena cabai banyak dimanfaatkan untuk keperluan rumah tangga maupun industri. Terdapat berbagai jenis cabai yang ada di Indonesia, tetapi cabai yang banyak dimanfaatkan sebagai bahan olahan adalah cabai merah besar. Sebagai komuditas tanaman hortikultura dengan fluktuasi harga yang tinggi konsumen mengharapkan kualitas yang baik pula pada proses produksi. Agar produksi cabai memiliki kualitas yang merata, cabai hasil panen harus diklasifikasikan sebelum proses distribusi. Saat ini proses klasifikasi cabai di kota Blitar masih dilakukan secara manual oleh pegawai terkait.

Algoritma FKNN memberikan nilai keanggotaan kelas pada vektor dan bukan menempatkan vektor pada kelas tertentu. Data didapat dari Dinas Pertanian, Peternakan, dan Perikanan Kota Blitar pada tahun 2015. Penelitian ini menggunakan 100 data sampel dengan 70 data latih dan 30 data uji. Dari pengujian didapatkan akurasi 96,67\% terhadap data sampel. Maka dapat disimpulkan bahwa penelitian menggunakan metode Fuzzy K-Nearest Neighbor $(F K N N)$ memiliki kinerja yang baik dalam klasifikasi kualitas cabai di kota Blitar.
\end{abstract}

Kata kunci :Klasifikasi, Fuzzy K-Nearest Neighbor, Cabai Merah Besar

\section{Pendahuluan}

\subsection{Latar Belakang}

Sayuran merupakan salah satu produk hortikultura yang banyak diminati oleh masyarakat karena memiliki kandungan gizi yang bermanfaat bagi kesehatan. Terutama cabai yang yang memiliki kandungan Kalori, Protein, Lemak, Kabohidarat, Kalsium, Vitamin A, B1 dan Vitamin C serta mengandung minyak atsiri capsaicin, yang menyebabkan rasa pedas dan memberikan kehangatan bila digunakan untuk rempah-rempah (bumbu dapur), kandungan dalam zat capsaicin juga berfungsi dalam mengendalikan penyakit kanker. Selain digunakan untuk keperluan rumah tangga, cabai juga dapat digunakan untuk keperluan industri diantaranya, industri bumbu masakan, industri makanan dan industri obat-obatan atau jamu. Terdapat berbagai jenis cabai yang ada di Indonesia, tetapi cabai yang banyak dimanfaatkan sebagai bahan olahan adalah cabai merah besar. Meningkatnya kualitas cabai yang semakin tinggi membuat cabai sebagai komuditas hortikultura yang mengalami fluktuasi harga paling tinggi di Indonesia. Dengan fluktuasi harga yang tinggi diharapkan produksi cabai mempunyai kualitas yang baik pula. Maka dari itu di butuhkan klasifikasi cabai untuk menjaga kualitas cabai agar hasil produksi cabai di indonesia dapat semakin mengingkat.

Manfaat yang diharapkan pada pembuatan aplikasi klasifikasi cabai adalah untuk membantu pengguna dalam mengklasifikasikan kualitas cabai merah besar. Dengan adanya sistem yang dapat mengklasifikasikan kualitas cabai, kualitas cabai merah besar di pasar dapat terjaga.

Untuk menentukan kualitas cabai yang baik para peneliti pada bidang hortikultura sudah menentukan standart kualitas cabai yang baik. Pada penelitian kali ini menggunakan dari Balai Penelitian Tanaman dan Sayuran Bandung pada tahun 2011. Kriteria pada yang sudah ditentukan standat mutunya antara lain adalah panjang buah cabai, diameter cabai, berat perbuah, dan kekerasan buah cabai. Dari kriteria tersebut cabai merah besar akan di klasifikasikan apakah cabai yang akan di pasarkan sudah memenuhi standart kualitas cabai ataukah tidak.

Proses kliasifikasi pada penelitian ini dibangun menggunakan metode Fuzzy K-Nearest Neighbor (FKNN), metode FKNN memiliki dua keunggulan utama dari pada dari pada algoritma KNearest Neighbor. Pertama, algoritma ini mampu mempertimbangkan sifat ambigu dari tetangga jika ada. Algoritma ini sudah dirancang sedemikian rupa 
agar tetangga yang ambigu tidak memainkan peranan penting dalam klasifikasi.

Keunggulan kedua yaitu sebuah interface akan memiliki derajat nilai keanggotaan pada setiap kelas sehingga akan lebih memberikan kekuatan atau kepercayaan suatu intance yang berada pada suatu kelas. Dengan menerapka metode Fuzzy $K$ Nearest Neighbor (FKNN) pada proses klasifikasi kualitas cabai, maka proses klasifikasi bisa dilakukan dengan lebih objektif(Yanita Selly Meriska, Achmad Ridhok, dan Lailil Muflikhah, 2014).

\section{Landasan Teori}

\subsection{Kualitas Cabai}

Adapun tipe cabai unggul adalah memiliki pembungaan dan pembentukan buahnya cepat (umur panen genjah), produktivitasnya tinggi, daya adaptasinya luas atau spesifik untuk daerah marginal tertentu (kering, rawa, pantai, gambut/asam), serta tahan terhadap hama dan penyakit. Tak hanya untuk memenuhi hasil secara kuantitas, penentuan cabai unggul juga ditekankan pada kualitas sesuai dengan preferensi konsumen. Para konsumen menginginkan karakter cabai antara lain tingkat kepedasan sesuai, penampilan buah yang baik, mulus, dan warna yang terang, serta bebas dari penyakit. Untuk industri pangan, seperti saos dan pasta, sifat-sifat cabai yang diinginkan adalah mempunyai tingkat kepedasan tinggi, warna merah terang, dan buahnya harus tersedia sepanjang waktu untuk memenuhi kebutuhan industri (kontinuitas terjaga)(Dr. Ir. Kasdi Subagyono, M.Sc, 2010).

Adapun kualitas cabai akan ditentukan berdasarkan varietas cabai sebagai berikut:

Tabel 1 Mutu Fisik Cabai Merah

\begin{tabular}{|ll|}
\hline \multicolumn{1}{|c|}{$\begin{array}{c}\text { Kualitas(Quality) } \\
\text { Mutu Fisik (Physical } \\
\text { quality) }\end{array}$} & \multicolumn{1}{c|}{ Varietas (Varieties) } \\
\hline $\begin{array}{l}\text { Panjang buah (fruit } \\
\text { length) }\end{array}$ & $\begin{array}{l}11.16 \pm 1.38 \mathrm{~cm} \\
\text { Range: } 9-14 \mathrm{~cm}\end{array}$ \\
$\begin{array}{l}\text { Diameter buah (base of } \\
\text { fruit diameter) }\end{array}$ & $1.66 \pm 0.13 \mathrm{~cm}$ \\
Berat per buah (weight & Range: $1.5-1.85 \mathrm{~cm}$ \\
per fruit) & $14.2 \pm 3.44 \mathrm{~g}$ \\
Kekerasan buah & Range: $9.22-20.38 \mathrm{~g}$ \\
(hardness) & $1.53 \pm 0,34 \mathrm{~mm} / 50 \mathrm{~g} / \mathrm{s}$ \\
\hline
\end{tabular}

Sumber : Balai Penelitian Tanaman Sayuran Bandung, 2011

\subsection{Klasifikasi}

Klasifikasi adalah suatu proses pengelompokan data ke dalam kelas tertentu yang diberikan berdasarkan sifat dan pola dalam suatu data pembelajaran. Klasifikasi juga dapat diartikan suatu teknik dengan melihat kelakuan data dan atribut suatu kelompok yang telah diklasifikasikan. Teknik ini dapat memberikan klasifikasi pada data baru dengan melakukan manipulasi data yang telah didefinisikan dan dengan menggunakan hasil untuk memberikan sejumlah aturan(Faris Fitrianto, Rekyan Regasri, Nurul Hidayat, 2014).

\subsection{Logika Fuzzy}

Himpunan Fuzzy didasarkan pada gagasan untuk memperluas jangkauan fungsi karakteristik sedemikian hingga fungsi tersebut akan mencakup bilangan real pada interval $[0,1]$. Nilai keanggotaannya menunjukkan bahwa suatu item dalam semesta pembicaraan tidak hanya berada pada 0 atau 1, namun juga nilai yang terletak diantaranya. Dengan kata lain, nilai kebenaran suatu item tidak hanya benar atau salah. Nilai 0 menunjukkan salah, nilai 1 menunjukkan benar, dan masih ada nilai-nilai yang terletak antara benar dan salah(Hardika Teguh W, Mardji, M. Tanzil Furqon, 2014).

Himpunan tegas (crisp) A didefinisikan oleh item-item yang ada pada himpunan itu. Pada himpunan tegas (crisp), nilai keanggotaan suatu item $\mathrm{x}$ dalam suatu himpunan $\mathrm{A}(\mu \mathrm{A}(\mathrm{x}))$ memiliki dua kemungkinan, yaitu:

1. Satu (1), yang berarti bahwa suatu item menjadi anggota dalam suatu himpunan.

2. Nol (0), yang berarti bahwa suatu item tidak menjadi anggota dalam suatu himpunan.

\section{$2.4 \quad$ K-Nearest Neighbor $(K N N)$}

Algoritma K-Nearest Neighbor(KNN) adalah sebuah metode untuk melakukan klasifikasi terhadap objek berdasarkan data pembelajaran yang jarak paling dekat dengan objek tersebut. Data pembelajaran diproyeksikan ke ruang berdimensi banyak, dimana masing-masing dimensi mempresentasikan fitur dari data. Ruang ini dibagi menjadi bagian-bagian berdasarkan klasifikasi data pembelajaran. Sebuah titik pada ruang ini ditandai kelas c jika kelas c merupakan klasifikasi yang paling banyak ditemui pada $\mathrm{k}$ buah tetangga terdekat titik tersebut. Dekat atau jauhnya tetangga biasanya dihitung berdasarkan jarak euclidean (Hardika Teguh, Mardji, dan M. Tanzil Furqon, 2014).

Pada fase training, algoritma ini hanya melakukan penyimpanan vector-vektor fitur dan klasifikasi data training sample. Pada fase klasifikasi, fitur - fitur yang sama dihitung untuk testing data(klasifikasinya belum diketahui). Jarak dari vektor yang baru ini terhadap seluruh vektor training sample dihitung, dan sejumlah $k$ buah yang paling dekat diambil. Titik yang baru klasifikasinya diprediksikan termasuk pada klasifikasi terbanyak dari titik - titik tersebut. Adapun algoritma dari KNN ditunjukan pada Gambar 1. 


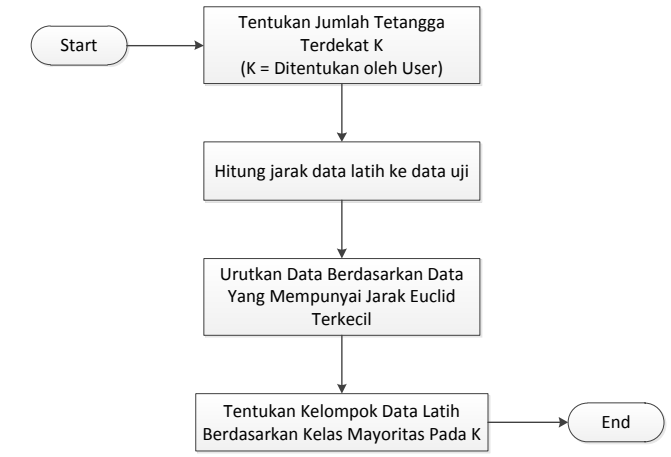

Gambar 1Flowchart algoritma metode K-Nearest Neighbor

\subsection{Fuzzy K-Nearest Neighbor(FKNN)}

Fuzzy K-Nearest Neighbor (FKNN) merupakan metode klasifikasi yang digunakan untuk memprediksi data uji menggunakan nilai derajat keanggotaan data uji pada setiap kelas. Kemudian diambil kelas dengan nilai derajat keanggotaan terbesar dari data uji sebagai kelas hasil prediksi. Fuzzy K-Nearest Neighbor (FKNN) merupakan metode klasifikasi yang menggabungkan teknikFuzzydengan K-Nearest Neighbor classifier.Keuntungannya adalah nilai-nilai keanggotaan vektor seharusnya memberikan tingkat jaminan pada hasil klasifikasi (Hardika Teguh W, Mardji, M. Tanzil Furqon, 2014).

\section{Perancangan dan Implementasi}

\subsection{Pengolahan Data}

Proses pengolahan data pada perhitungan algotritma FKNN(Fuzzy K- Nearest Neighbor) dapat dilihat pada kerangka Gambar 2.

\begin{tabular}{|c|c|c|c|c|}
\hline Input & Normali & Perhitun & Perhitun & Hasil \\
\hline
\end{tabular}

Gambar 2 Proses Perhitungan FKNN

Dari gambar proses 2 Proses Perhitungan FKNN dapat dijelaskan dengan menggunakan proses perhitungan metode FKNN(Fuzzy K-Nearest Neighbor), yaitu seperti berikut:

1. Proses input data uji dan data latih yang akan diproses menggunakan metode FKNN.

2. Melakukan perhitungan normalisasi atribut menggunakan min - max normalization.

3. Proses KNN yaitu menghitung nilai kedekatan data uji pada data latih (euclidean distance) kemudian mengambil mayoritas kelas pada $\mathrm{K}$ yang telah ditentukan sebagai kelas target pada data yang baru.

4. Proses FKNN yaitu menghitung nilai derajat keanggotaan dan mengambil nilai terbesar dari proses tersebut dan menentukan kelas target.

5. Penghitungan nilai akurasi metode FKNN pada data latih yang digunakan.

Dari langkah-langkah diatas terdapat rumus untuk menyelesaikan proses tersebut antara lain adalah formula untuk melakukan normalisasi:

$$
\text { data normalisasi }=\left(\frac{x-\min (x)}{\operatorname{range}(x)}\right)(1)
$$

Keterangan :

$\mathrm{x}=$ Data

$\min (\mathrm{x})=$ Nilai data minimum

range $(\mathrm{x})=$ Jarak antara data minimum dan maximum

$$
\mathrm{di}=\sqrt{\sum_{i=1}^{p}(\mathrm{x} 2 \mathrm{i}-\mathrm{x} 1 \mathrm{i})^{2}}
$$

Keterangan :

$\mathrm{x} 1$ : Data latih(sample data)

d : Jarak

x2 : Data uji(data training)

$\mathrm{p}$ : Dimensi data

i : Variabel data

Sebelum melakukan perhitungan FKNN terlebih dahulu menentukan kelas data pada suatu data latih dengan persamaan (3) :

$$
U i j_{j}=\left\{\begin{array}{c}
0.51+\left(\frac{n_{j}}{n}\right) * 0.49, j i k a j=i \\
\left(\frac{n_{j}}{n}\right) * 0.49, \quad \text { jika } j \neq i
\end{array}\right\}
$$

Keterangan :

$n_{j}=$ Jumlah anggota kelas $j$ pada suatu data latih $n$ $n=$ Jumlah data latih yang digunakan

$j=$ Kelas data $(1=$ layak jual, $0=$ tidak layak $)$

$i=$ Hasil data latih

Selanjutnya masukkan hasil normalisasi ke dalam algoritma perhitungan FKNN(Fuzzy K-Nearest Neighbor) dengan persamaan (4):

$$
U i(x)=\frac{\sum_{j=1}^{k} U i j\left(|x-x j|^{\frac{-z}{(m-1)}}\right)}{\sum_{j=1}^{k}\left(\mid x-x j \|^{\frac{-2}{(m-1)}}\right)}
$$

Keterangan :

$U i(x)=$ Nilai keanggotaan data $\mathrm{x}$ ke kelas $\mathrm{i}$

$k=$ Jumlah tetangga terdekat yang dugunakan

$U i j=$ Nilai keanggotaan kelas $\mathrm{i}$ pada vektor $\mathrm{j}$ 
$x-x j=$ Selisih jarak dari data $\mathrm{x}$ ke data $\mathrm{xj}$ dalam $\mathrm{k}$ tetangga terdekat

$m=$ Bobot pangkat (weight exponent) yang besarnya $m>1$

Algoritma Fuzzy K-Nearest Neighbor juga dapat ditulis menggunakan kode seperti pada Gambar3.

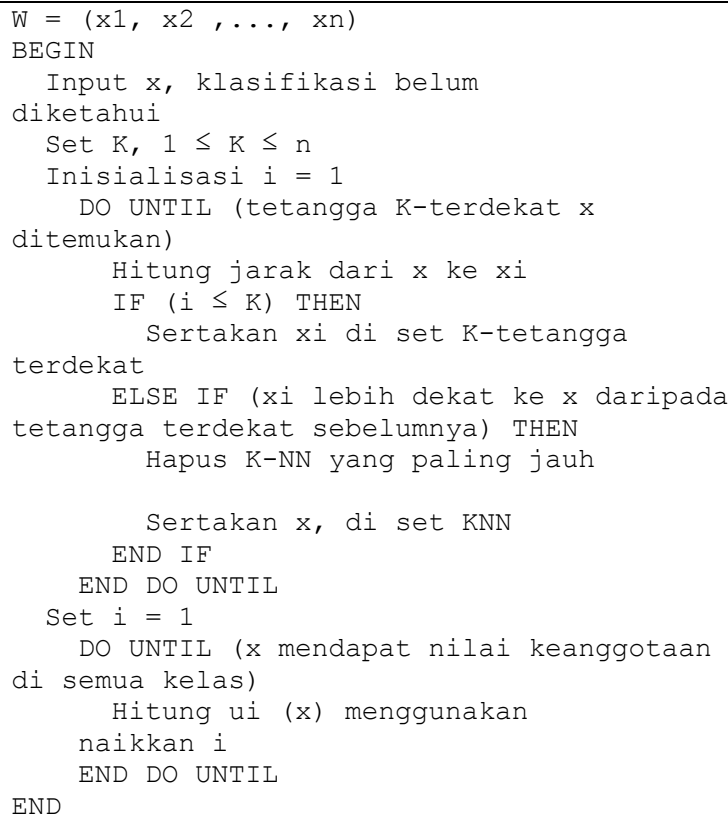

Gambar 3PseudocodeFuzzy K-Nearest Neighbor

Secara umum, gambaran sistem dapat dilihat pada WBS(Work Breakdown Structure) pada Gambar 4

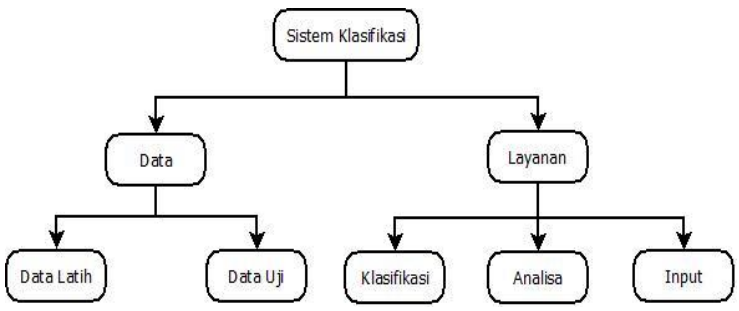

Gambar 4 WBS (Work Breakdown Structure)

Arsitektur pada Gambar 4 menjelaskan tahaptahap pengerjaan pembuatan aplikasi serta fitur-fitur pada aplikasi yang akan dibuat. Dalam WBS diatas di dijelaskan tentang data dan layanan yang ada pada aplikasi yang akan dibuat. Pada sisi data terdapat dataset dan kriteria, serta pada sisi layanan aplikasi menyediakan fungsi berupa analisa dan input.Untuk alur kerja sistem yang berjalan pertama user akan memasukan parameter yang digunakan untuk memilah kualitas cabai yang akan di tentukan kualitasnya. Kemudian sistem akan memcocokan data masukan yang baru (data uji) dan dicocokan dengan data yang ada (data latih). Seberapa banyak kecocokan yang ditemukan pada suatu jenis cabai yang di masukan kemudian ditentukan berapa persen kualitas cabai sebagai bahan untuk menentukan kualitas.

\subsection{Implementasi}

Sistem klasifikasi cabai menggunakan metode Fuzzy K-Nearest Neighbor ini diimplementasikan berbasis desktop. Pengguna pada sistem ini adalah pegawai dari Dinas Pertanian Kota Blitar. Proses dari klasifikasi cabai pada sistem ini dibagi menjadi tiga tahap yaitu perhitungan nilai normalisasi dataset, perhitungan nilai euclideance distance, dan perhitungan Fuzzy K-Nearest Neighbor. Berikut adalah hasil klasifikasi menggunakan 70 data latih seperti pada Gambar 5.

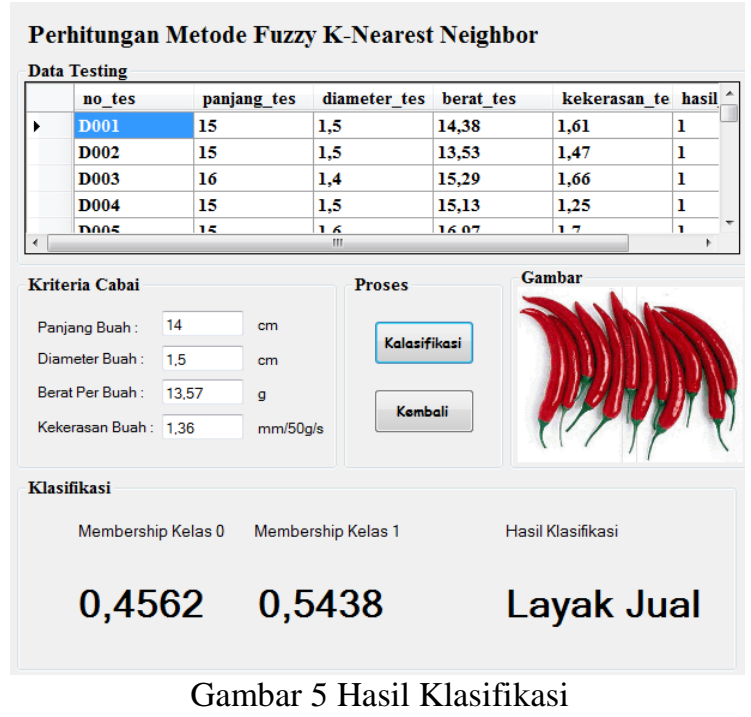

\subsection{Pengujian}

Pengujian perangakat lunak adalah elemen kritis dari jaminan kualitas perangkat lunak dan mepresentasikan kajian pokok dari spesifikasi, desain, dan pengkodean. Pengujian yang digunakan dalam penelitian kali ini menggunakan akurasi. Akurasi adalah hasil pengukuran seberapa dekat suatu angka hasil terhadap angka sebenarnya (true value or reference value). Dalam penelitian ini akurasi hasil dihitung dari jumlah hasil yang tepat dibagi dengan jumlah data. Tingkat akurasi diperoleh dengan perhitungan sesuai dengan persamaan 5 .

Akurasi $(\%)=\frac{\sum \text { Data Uji Benar }}{\sum \text { Total Data Uji }} \times 100 \%$

Jumlah prediksi benar adalah jumlah record data uji yang diprediksi kelasnya menggunakan metode klasifikasi dan hasilnya sama dengan kelas sebenarnya. Sedangkan jumlah total prediksi adalah 
jumlah keseluruhan record yang diprediksi kelasnya (seluruh data uji).

Setelah sistem dapat melakukan klasifikasi pada data uji. Dilakukan pengujian data pada data uji menggunakan 30 data uji menggunakan persamaan (5). Pada proses pengujian tersebut didapatkan hasil seperti pada Gambar 6.

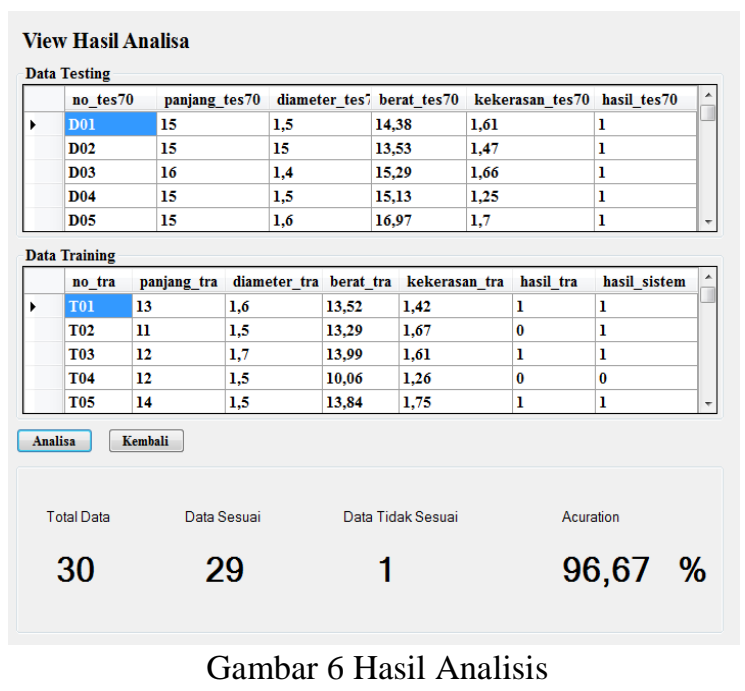

\section{Kesimpulan dan Saran}

\subsection{Kesimpulan}

Berdasarkan penelitian yang telah dilakukan yang telah dibahaspada bab 1 hingga bab 6 , maka dapat disimpulkan bahwa :

1. Implementasi Sistem Klasifikasi Kualitas Tanaman Cabai Menggunakan Metode Fuzzy K-Nearest Neighbor yang dibangun sesuai dengan perancangan yang telah dibuat.

2. Sistem dapat mengklasifikasikan cabai merah besar sesuai dengan data sampel yang didapatkan.

3. Tingkat akurasi sistem klasifikasi tanaman cabai menggunakan metode Fuzzy K-Nearest Neighbor dengan 30 data training dan 70 data testing mencapai $96,67 \%$.

\subsection{Saran}

Saran yang diberikan untuk pengembangan sistem ini ke depannya adalah sebagai berikut :

1. Diharapkan pada pengembangan aplikasi selanjutnya dapat menggunakan data sampel yang lebih banyak agar hasil klasifikasi memiliki akurasi lebih tinggi.

2. Pada pengembangan aplikasi selanjutnya diharapkan pada proses klasifikasi dapat mengklasifikasikan berbagai jenis cabai.

\section{Daftar Pustaka}

Achmad Zaki. M, Achmad Ridok, Yusi Tyroni M. 2014., Penerapan Metode FuzzyK-NN Pada Klasifikasi Mangga Berdasarkan Tekstur Daun. Program studi informatika / Ilmu komputer Universitas Brawijaya.

Alfian Sukma, Dian Ramadhan, Bagus Puji Santoso, Tiara Ratna Sari, Ni Made Ayu Karina Wiraswari. 2014., K-Nearest Neighbor Information Retrieval (Sistem Temu Kembali Informasi). Fakultas Saint dan Teknologi/Sistem Informasi Universitas Airlangga.

Alisandi, Robi. 2015. Contoh Pengujian Fungsional atau Sering Disebut Black Box. [Online] Tersedia:http://robialisandii.blogspot.co.id/20 15/05/contoh-pengujian-fungsional-atausering.html

Faris Fitrianto, Rekyan Regasari, Nurul Hidayat. 2014., Implementasi Algoritma Fuzzy $K$ Neares Neighbor (FKNN) pada Deteksi Potensi Bencana Alam Tsunami. Program studi informatika / Ilmu komputer Universitas Brawijaya.

Hardika Teguh Wijaya, Mardji, M. Tanzil Furqon. 2014., Penerapan Fuzzy K-Nearest Neighbor (FKNN) Untuk Diagnosa Penderita Liver Berdasarkan Indian Liver Patient Dataset (ILPD).Program studi informatika/ Ilmu komputer Universitas Brawijaya.

Kasdi Subagyono, 2010. Badan Pengembangan dan Penelitian Pertanian : Budidaya dan Pasca Panen Cabai Merah. Jawa Tengah: Balai Pengkajian Teknologi Pertanian.

Soetiarso, T.A., W. Setiawati, D. Musaddad, 2011. Balai Penelitian Tanaman Sayuran :Keragaman Pertumbuhan, Kualitas Buah, Kelayakan Finansial Dua Varietas Cabai Merah. Jawa Barat: Balai Penelitian Tanaman Sayuran.

Yanita Selly Meristika, Achmad Ridhok, Lailil Muflikhah.2014., PerbandinganK-Nearest Neighbor dan Fuzzy K-Nearest Neighbor pada DiagnosisPenyakit Diabetes Melitus. Program studi informatika/ Ilmu computer Universitas Brawijaya. 